\title{
Chemical characterization and antibacterial activity of the essential oils of Tetraclinis articulata (Vahl) from Morocco
}

\author{
Hannou Zerkani ${ }^{1, *}$, Imane Tagnaout ${ }^{1}$, Aziz Dirioiche ${ }^{1}$, Imad Adadi ${ }^{1}$, Jamila El Karkouri ${ }^{1}$, Hicham \\ Aaziz $^{1}$, Guy Stéphane Padzys ${ }^{2}$ and Touriya Zair ${ }^{1}$ \\ ${ }^{1}$ Department of chemistry, Research Team: chemistry of bioactive molecules and the environment, Faculty of \\ Science, University Moulay Ismail, PO Box. 11201, Zitoune Meknes, Morocco \\ ${ }^{2}$ Department of Biology, Faculty of Science University of Science and Technology of Masuku, \\ PO Box 943 Franceville, Gabon
}

\begin{abstract}
The objective of this study was to identify new bioactive substances through the phytochemical study and evaluation of the antibacterial activity of the essential oils of Tetraclinis articulata (Vahl). Harvested in April 2016, in the region of Khenifra (Middle Atlas-Morocco).
\end{abstract}

Separate of hydrodistillation extracts of the three organs (branches, leaves and fruits) of Tetraclinis articulate were performed. The yields of essential oils are $0.92 \%$ for fruits; $0.41 \%$ for branches and $0.61 \%$ for leaves.

The GC/MS analysis allowed the identification of 33 compounds in essential oil leaves, 20 compounds in excess fruits and 58 compounds in branches. The main compounds are bornyl acetate (38.54\%) and $\alpha$-pinene $(6.71 \%)$ for leaves. $\alpha$-pinene $(22.12 \%)$; 13-epi-mannol (3.58\%) and retinol (3.44\%) for branches. Bornyl acetate (19.96\%); $\alpha$-pinene (12.47\%) and retinol (11.98\%) for fruits.

The antibacterial properties of the essential oil of leaves of Tetraclinis articulata (Vahl) were tested in clinical bacterial strain. The essential oils inhibit the growth of Escherichia coli, Staphylococcus aureus and Klebsiella pneumoniae at $1.2 \mu \mathrm{l} / \mathrm{ml} ; 2.4 \mu \mathrm{l} / \mathrm{ml}$ and $9.7 \mu \mathrm{l} / \mathrm{ml}$ respectively.

Indeed, the resistance of bacteria to antibiotics is known for its adverse effects on human health, to escape this problem, it is necessary to exploit the antibiotics from aromatic and medicinal plants.

Keywords: Tetraclinis articulata (Vahl), Essential oils, chemical composition, antimicrobial properties.

\section{Introduction}

Microbial infections have been successfully managed using medicinal plants. However, most drugs, such as microbially derived antibiotics, have been considered almost universal solutions to severe infections and have a low antimicrobial spectrum and side effects on human health. Their widespread and excessive use leads to resistance of microorganisms. Indeed, the resurgence of bacterial and fungal resistance is currently one of the obstacles to the successful treatment of microbial diseases by antibiotics. The side effects induced by antibiotics are of concern to users and increase the universal demand for herbal medicine, especially in developing countries.

Tetraclinis artciulata or Berber Thuya is the only species representing the genre Tertraclinis (Cupressaceae) in the northern hemisphere ${ }^{1}$. It is an endemic species of the southwestern Mediterranean and especially the Maghreb ${ }^{2}$. T. articulata (Vahl) plays a considerable role in the protection of the soil. Indeed, this species can grow under challenging conditions ${ }^{3}$. Tetraclinis articulata (Vahl) has been used since antiquity in traditional medicine, in the seventeenth century, it was nicknamed "tree of life" because of its medicinal properties attributed to the balsamic resin known to increase blood pressure and lower fever ${ }^{4}$. Indeed, many studies mention that local Moroccan populations use this plant in traditional medicine. Specifically, the population of the Khenifra region regularly uses this forest species to treat several diseases, as mentioned by Hachi ${ }^{5}$ in their report of the floristic and ethnobotanical study of the medicinal flora used in the town of Khenifra (Morocco) that leaf decoctions of T. $\operatorname{articulata(Vahl)}$ are indicated for the treatment of gastrointestinal pain. Another ethnobotanical study on aromatic and medicinal plants (PAM) showed that this tree is 
classified as the second species for very therapeutic use $^{6}$.

Also as reported in an ethnopharmacological study conducted in Morocco that the leaves of T. articulata (Vahl) are used against diabetes and hypertension 7. Different organs of the tree, especially leave and twigs, are used in the treatment of intestinal and respiratory infections ${ }^{8}$ (Bellakhdar et al., 1997).

Several studies have reported on the evaluation of the biological activities of the essential oils of T.articulata (Vahl). Indeed, some studies have shown that essential oils of the various organs of this tree have antimicrobial, antioxidant and antiinflammatory properties ${ }^{9}$.

The objective of this work is to contribute to the valorization of this species by studying the chemical composition and the antibacterial activity of the essential oils isolated from the leaves, fruits and branches of T.articulata (Vahl).

\section{Experimental}

\section{Plant material}

The organs of T.articulata (Vahl) were harvested in the Khenifra region (Moyen Atlas-Morocco) during April (2013). The leaves, fruits and twigs harvested were dried in the shade for ten days. The taxonomic identification of T.articulata (Vahl) was made at the scientific institute of Mohammed University at Agdal in Rabat from the Herbarium flora of Morocco.

\section{Hydrodistillation of essential oils}

Essential oils extracted from different parts of Tetraclinis articulata (Vahl) was carried out by the hydrodistillation technique using a Clevenger apparatus ${ }^{10}$. During each test, $100 \mathrm{~g}$ of plant material was treated. The extraction time was three hours. Previously, the humidity content of the various samples was determined in order to express the total of essential oil (volume in $\mathrm{ml}$ ) relative to $100 \mathrm{~g}$ of the dry matter. The essential oils were dried over anhydrous sodium sulphate ${ }^{11}$, and stored at a temperature of $4^{\circ} \mathrm{C}$ in the dark until use.

Analysis and identification of the chemical composition of essential oil

The chromatographic analysis of the essential oils of T.articulata (Vahl) was performed using a gas chromatograph Thermo Electron type (Trace GC Ultra) coupled to a mass spectrometer type Thermo Electron Trace MS system (Thermo Electron: Trace Ultra GC, Polaris Q MS), the fragmentation is performed by electronic impact intensity of $70 \mathrm{eV}$. The chromatograph is equipped with a column of type DB-5 (5\% phenyl-methyl-siloxane) (30m $\times 0.25 \mathrm{~mm} \times 0.25 \mu \mathrm{m}$ film thickness), a flame ionization detector (FID) powered by a mixture of $\mathrm{H} 2$ / Air gas. The temperature of the column is programmed at a rate of $4^{\circ} \mathrm{C} / \min$ from 50 to $200^{\circ}$ $\mathrm{C}$ for $5 \mathrm{~min}$. The injection mode is split (leakage ratio: $1 / 70, \mathrm{ml} / \mathrm{min}$ flow rate); the carrier gas used is nitrogen with a flow rate of $1 \mathrm{ml} / \mathrm{min}$.

Identification of the chemical composition of T.articulata (Vahl) essential oils was performed based on the comparison of their Kovats (IK) and Adams indices with those of known reference products in the literature ${ }^{12,13}$. It was supplemented by a comparison of indices and mass spectra with different.

The Kováts index_compares the retention time of any product with that of a linear alkane of the same carbon number. They are determined by injecting a mixture of alkanes (standard C7-C40) under the same operating conditions.

\section{Microorganisms, antibiotics and media}

Commercially available antibiotics discs (Ciproflaxin $5 \mu \mathrm{g}$ ). The selection of clinical microorganisms depended on their availability, thus microorganisms that have been reported to be the most frequently implicated in infectious diseases. The clinical isolates (Hospital center Mohamed V of Meknes-Morocco) were Staphylococcus aureus (Gram-positive), Escherichia coli (Gram-negative), Klebsiella pneumoniae (Gram-negative).

\section{Antibacterial assays}

The assay was conducted as described by Perez et al. ${ }^{14}$. Briefly, microorganisms from growth on nutrient agar incubated at $37{ }^{\circ} \mathrm{C}$ for $18 \mathrm{~h}$ were suspended in saline solution $0.9 \% \mathrm{NaCl}$ and adjusted to a turbidity of 0.5 Mac Farland standards $\left(10^{8} \mathrm{CFU} / \mathrm{ml}\right)^{15}$. The suspension was inoculated onto $90 \mathrm{~mm}$ diameter Petri plates with a sterile, nontoxic cotton swab on a wooden applicator. Wells with a diameter of five millimetres were punched in the agar and filled with $5 \mu 1$ of essential oil. The dissolution of the extract was added in $0.5 \%(\mathrm{v} / \mathrm{v})$ DMSO, which did not affect microorganism growth, according to our control experiments. Commercial antibiotics were used as positive reference standard to determine the sensitivity of the strains. Discs were directly placed onto the bacterial culture. Plates were incubated aerobically at 30 or $37^{\circ} \mathrm{C}$ for $24 \mathrm{~h}$. Antimicrobial activities were evaluated by measuring inhibition zone diameters (IZD).

Determination of minimum inhibitory MIC concentration and minimum bactericidal concentration (MBC)

The broth dilution method was used to determine minimal inhibitory concentrations (MIC) and minimal bactericidal concentrations (MBC) of the essential oils against the test microorganisms as recommended by the National Committee for Clinical Laboratory Standards. The tests were 
performed in test tubes. Essential oils were dissolved in $0.5 \%$ DMSO and transferred in tubes to obtain a two-fold serial dilutions ranging from 32,$8 ; 16 ; 9,7$, 4,$86 ; 2,4$ and $1,2 \mu 1 / \mathrm{ml}$. The tubes were inoculated with microbial suspensions diluted from the same 0.5 Mac Farland standards to have $10^{8} \mathrm{CFU} / \mathrm{mL}$ in each tube ${ }^{15}$. After $24 \mathrm{~h}$ incubation in the air at $37^{\circ} \mathrm{C}$, MIC was recorded as the lowest extract concentration demonstrating no visible growth in the broth. MBC was recorded as the lowest extract concentration that kills $99.9 \%$ of bacterial inocula. MBC values were determined by removing $100 \mu \mathrm{L}$ of bacterial suspension for subculture demonstrating no visible growth and by inoculating nutrient agar plates. Plates were incubated aerobically at $37^{\circ} \mathrm{C}$ for a total period of $48 \mathrm{~h}$.

\section{Results and Discussion} (Vahl)

Yields of essential oils of Tetraclinis articulata

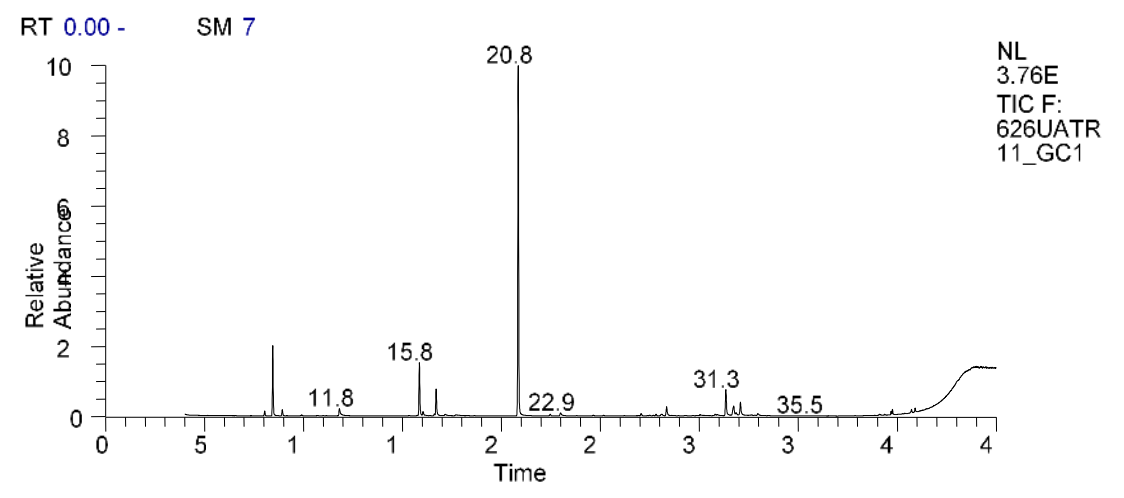

Figure 1. Chromatogram of the essential oils of the leaves of T.articulata (Vahl)

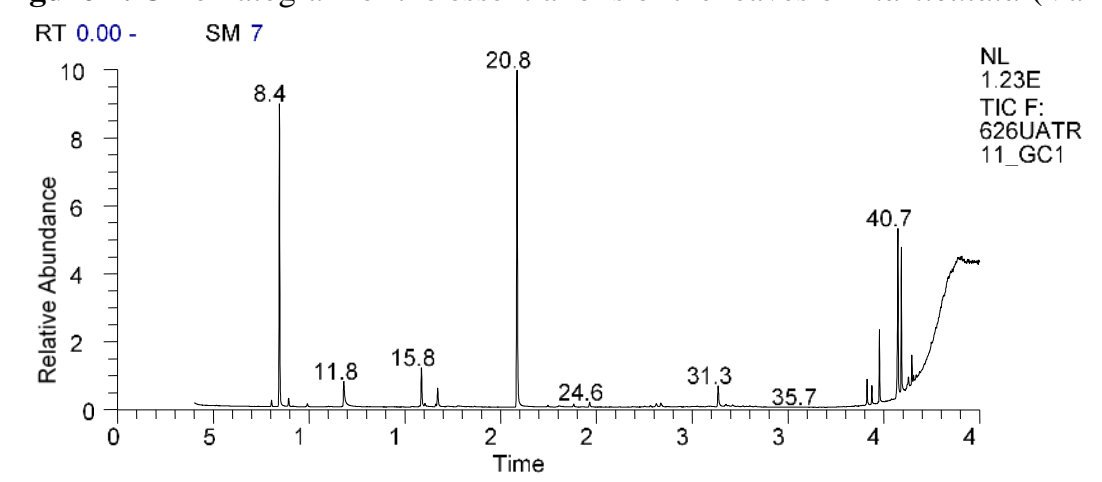

Figure 2. Chromatogram of the essential oils of the fruits of T. articulata (Vahl)

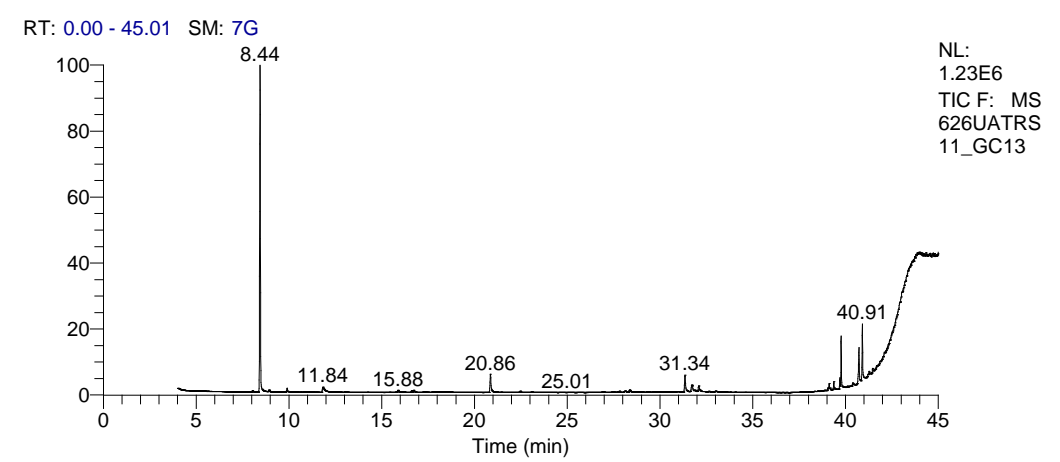

Figure 3. Chromatogram of the essential oils of the branches of T.articulata (Vahl)
The yields of essential oils from the leaves, branch and fruits of $T$. articulata (Vahl) are respectively $0.61 \% 0.41 \%$ and $0.92 \%$. The essential compared to that of the same organ of T.articulata(Vahl) from Khemisset-Morocco ${ }^{9}$ and Wilaya of Tiaret $(0.35 \%)$ (Algeria) ${ }^{16}$. However, the T.articulata (Vahl) of the Khemisset region (Morocco) ${ }^{17}$ is $0.41 \%$, similar to that obtained during this study.

The difference in yield can be attributed to several factors including which organ was used, the origin of the species, the period of harvest and the duration of drying.

The essential oils of leaves, branch and fruits of T.articulata (Vahl) were analyzed by gas chromatography coupled with mass spectrometry. The chromatograms for the three essential oils of the species are presented in Figures 1, 2 and 3.

. 
Table 1. Chemical composition of leaves, branches and fruits of T. articulata (Vahl).

\begin{tabular}{|c|c|c|c|c|c|c|}
\hline \multirow[t]{2}{*}{$\mathbf{N}$} & \multirow[t]{2}{*}{ Constituents } & \multirow{2}{*}{$\begin{array}{c}\text { IR } \\
\text { (Calculate) }\end{array}$} & \multirow{2}{*}{$\begin{array}{c}\text { IR } \\
\text { (Adams) }\end{array}$} & \multicolumn{3}{|c|}{ Percentage \% } \\
\hline & & & & leaves & branches & Fruits \\
\hline 1 & Tricyclene & 924 & 926 & 0.48 & 0.28 & 0.11 \\
\hline 2 & $\alpha$-Pinene & 933 & 939 & 6.71 & 12.47 & 22.12 \\
\hline 3 & Camphene & 948.92 & 954 & 0.70 & 0.40 & 0.27 \\
\hline 4 & Sabinene & 973.62 & 975 & 0.16 & 0.22 & 0.43 \\
\hline 5 & Limonene & 1028.33 & 1029 & 1.61 & 2.32 & 1.23 \\
\hline 6 & $\alpha$-Campholenal & 1122.33 & 1126 & 5.93 & 2.10 & 0.51 \\
\hline 7 & Borneol & 1165.25 & 1169 & 3.52 & 1.42 & 0.25 \\
\hline 8 & Terpinen-4-ol & 1177.06 & 1177 & 0.42 & -- & - \\
\hline 9 & $\alpha$-Terpineol & 1187.92 & 1188 & 0.52 & - & - \\
\hline 10 & $\gamma$-Terpineol & 1198.85 & 1199 & - & - & 0.45 \\
\hline 11 & Dihydrocarveol & 1194 & 1193 & - & 0.39 & \\
\hline 12 & Neo-dihydrocarveol & 1195 & 1194 & - & & 0.16 \\
\hline 13 & Bornyl acetate & 1285.25 & 1285 & 38.54 & 16.96 & 2.10 \\
\hline 14 & Neoiso- dihydrocarveol acetate & 1352.32 & 1359 & - & 0.25 & - \\
\hline 15 & $\alpha$-Terpinyl acetate & 1334.98 & 1349 & 0.78 & - & - \\
\hline 16 & $\alpha$-Copaene & 1375.85 & 1376 & 0.07 & 0.22 & - \\
\hline 17 & Sibirene & 1401 & 1400 & 0.15 & 0.44 & - \\
\hline 18 & (E)-Caryophyllene & 1419.34 & 1419 & 0.11 & - & - \\
\hline 19 & Germacrene D & 1481.31 & 1481 & 0.43 & - & - \\
\hline 20 & Trans-Muurola-4(14),5-diene & 1492.45 & 1493 & 0.06 & - & - \\
\hline 21 & $\gamma$-Amorphene & 1495.23 & 1495 & 0.13 & - & - \\
\hline 22 & $\alpha$-Muurolene & 1501 & 1500 & 0.11 & - & - \\
\hline 23 & Cubebol & 1516.83 & 1515 & 0.39 & 0.28 & 0.25 \\
\hline 24 & $\delta$-Cadinene & 1525.08 & 1523 & 1.35 & 0.36 & 0.49 \\
\hline 25 & $\gamma$-Cuprenene & 1533.08 & 1533 & 0.21 & - & - \\
\hline 26 & $\beta$-Vetivenen & 1556.07 & 1555 & 0.09 & - & - \\
\hline 27 & Caryophyllene oxide & 1583.16 & 1583 & 0.57 & 0.88 & - \\
\hline 28 & $\beta$-Oplopenone & 1609 & 1607 & 0.24 & 1.06 & - \\
\hline 29 & $\beta$-Atlantol & 1614 & 1608 & 0.30 & 0.11 & 0.27 \\
\hline 30 & 1-Epi-Cubenol & 1629 & 1628 & 3.49 & 1.41 & 1.83 \\
\hline 31 & Torreyol & 1642.90 & 1646 & 2.38 & 0.38 & 1.36 \\
\hline 32 & Valerianol & 1656.36 & 1658 & 2.14 & 0.24 & 0.95 \\
\hline 33 & Eudesma-4(15),7-dien-1 $\beta$-ol & 1689.09 & 1688 & 0.10 & 0.29 & 0.33 \\
\hline 34 & (3Z)-Cembrene A & 1994 & 1966 & 0.19 & 1.00 & 0.81 \\
\hline 35 & $\beta$-epi-Dolabradiene & 2021.68 & 2000 & 0.11 & 0.71 & 0.59 \\
\hline 36 & 13-epi-Mannol & 2068.67 & 2060 & - & 2.62 & 3.58 \\
\hline 37 & Retinol & 2240,35 & & 0.36 & $\begin{array}{l}11.98 \\
98\end{array}$ & 3.44 \\
\hline 38 & Trans-Ferrugunol & 2340 & 2332 & - & 1.07 & - \\
\hline \multicolumn{4}{|c|}{ Monoterpenes en $\%$} & 9.66 & 15.69 & 24.16 \\
\hline \multicolumn{4}{|c|}{ Sesquiterpenes en $\%$} & 2.71 & 1.02 & 0.49 \\
\hline \multicolumn{4}{|c|}{ Diterpenes en $\%$} & 0.3 & 1.71 & 0.59 \\
\hline \multicolumn{4}{|c|}{ Oxygenated monoterpenes en $\%$} & 11.18 & 4.26 & 1.46 \\
\hline \multicolumn{4}{|c|}{ Oxygenated sesquiterpenes en $\%$} & 9.61 & 4.65 & 4.99 \\
\hline \multicolumn{4}{|c|}{ Oxygenated diterpenes en $\%$} & 0.36 & 15.67 & 6.98 \\
\hline \multicolumn{4}{|c|}{ Esters en $\%$} & 39.32 & 17.21 & 2.10 \\
\hline \multicolumn{4}{|c|}{ Total } & $\underline{\underline{73.14}}$ & $\underline{\underline{60.16}}$ & 40.77 \\
\hline
\end{tabular}

The results obtained made it possible to identify 33 constituents representing approximately $73.14 \%$ of the chemical composition of the essential oil from the leaves of T.articulata (Vahl) (Figure 1) with the main compounds being: Bornyl acetate $(38.54 \%)$; $\alpha$-pinene (6.71\%); $\alpha$-campholenal (5.93\%), borneol
(3.52). 28 compounds representing a total of $60.16 \%$ of the essential oil isolated from the branches of T.articulata (Vahl) (Figure 2) with the main compounds being: Bornyl acetate (16.96\%); $\alpha$-pinene (12.47\%); retinol (11.98\%). 
Finally, 20 chemical compounds representing $40.77 \%$ of the essential oil from the fruit of T.articulata (Vahl) (Figure 3) with main compounds being: $\alpha$-pinene (22.12\%); 13-epi-mannol (3.58\%); retinol $(3.44 \%)$.

The essential oils of leaves and fruits have the same major compound (bornyl acetate) in different concentrations. Some of the compounds such as neoiso-dihydrocarveol acetate, dihydrocarveol, trans-ferruginol are absent in the essential oils of the leaves and fruits. By against that of the twigs, contains the percentages of $0.25 \%, 0.39 \%$ and $1.07 \%$ respectively. Also, we notice the absence of 13-epimannol in the essential oil of the leaves.

The absence of other compounds was found for the essential oils of fruits and branch such as $\beta$-vetivenen, $\gamma \quad$-cuprenene, $\alpha$-muurolene, $\gamma$-amorphene, muurola-4 (14),5-diene, germacrene $\mathrm{D},(E)$-caryophyllene, $\alpha$-terpinyl acetate, $\alpha$-terpineol and terpinen-4-ol compared to the leaves. It should be noted that the fraction of esters is the most abundant group of all the compounds identified for the leaves and twigs (39.32\%, 17.21\% respectively) whereas the most abundant group for fruits is monoterpene with a percentage of $24.16 \%$.

Several studies show that there is a difference in plant chemical composition by region. The leaves of T.articulata (Vahl) from the Khemisset region show a high concentration of $\alpha$-pinene and camphor (23.54\% and 17.27 respectively) ${ }^{9}$. The chemical composition of essential oils of T.articulata (Vahl) leaves of Tetouan origin (Morocco) identified by Barrero et al. in 2005 is characterized by the dominance of camphor (19.10\%), bornyl acetate $(16.50 \%)$ and bornéol $(9.60 \%){ }^{18}$, different from the results of this study. Also, essential oils isolated from leaves of T.articulata (Vahl) from El Haçaiba region (Algeria) identified by Toumi et al. in 2010 contains camphor $(26.67 \%)$, bornyl acetate $(25.79 \%)$. \%), borneol (12.96\%), and $\alpha$-pinene (3.65\%) ${ }^{18}$. In Algeria, in the region of Ouled Mimoun the essential oils contained camphor $(31.60 \%)$, bornyl acetate (17.12\%), borneol $(14.27 \%)$, Limonene $(3.0 \%)$ and a-pinene $(6.49 \%)^{16}$. The results of another study also show that the essential oil isolated from the branches of T.articluata (Vahl), harvested in the region of Khemisset (Morocco) is characterized by the dominance of $\alpha$-pinene $(30.22 \%)$, Limonene $(22.29 \%)$, widdrol $(5.41 \%)$, bornyl acetate $(4.76 \%)$ and humulene (3.49), ${ }^{17}$, which is different from the results of this study. All the results obtained have shown that the chemical profile of the essential oil of the leaves, branch and fruits of T.articulata (Vahl) varies qualitatively and quantitatively according to the organ. Those who demonstrate the importance of the plant material used to extract the essential oil. The difference observed between the chemical composition of the essential oils of T.articulata (Vahl) of the Khénifra region with other regions of Morocco and those of Algeria, could be explained by the adaptation of T.articulata (Vahl) to several factors such as altitude, climate and soil type, all of these factors can direct the biosynthesis to the formation of specific products.

\section{Antibacterial activity of the essential oil}

The results of the susceptibility tests are shown in Table 2. The antibacterial activity of essential oil from the leaves of T.articulata (Vahl) against the bacteria used was qualitatively and quantitatively evaluated by the presence or absence of zones inhibition. It was found from the analysis of the results obtained (Table 2) that all three microorganisms studied are sensitive to the essential oil of the leaves of T.articulata (Vahl). The inhibition diameters are for $S$. aureus $(14.23 \pm 0,22$ $\mathrm{mm})$ E. coli $(11,91 \pm 0,11 \mathrm{~mm})$ and $K$. pneumoniae $(10.41 \pm 0.27 \mathrm{~mm})$.

Table 2. Average of diameters of the zones of inhibition of the essential oils relative to the clinical bacterial strains:

\begin{tabular}{|l|l|l|}
\hline \multirow{2}{*}{ Strains } & Inhibition zone diameters $(\mathbf{m m})$ & \\
\cline { 2 - 3 } & T. articulata $($ Vahl $)(5 \mu \mathrm{l})$ & Ciprofloxacin $(5 \mu \mathrm{l})$ \\
\hline Staphylococcus aureus & $14.23 \pm 0.22$ & $18 \pm 0$ \\
\hline Escherichia coli & $11.91 \pm 0.11$ & $17.00 \pm 0$ \\
\hline Klebsiella pneumoniae & $10.41 \pm 0.27$ & $15.00 \pm 0$ \\
\hline
\end{tabular}

Table 3. Minimal inhibitory and bactericidal concentrations (MIC and MBC) for essential oil leaves

\begin{tabular}{|c|c|c|c|c|c|c|c|c|}
\hline \multicolumn{2}{|c|}{ Concentrations $(\mu \mathrm{l} / \mathrm{ml})$} & 32.8 & 16 & 9.7 & 4.86 & 2.4 & 1.2 & control \\
\hline \multirow[t]{2}{*}{ S. aureus } & MIC & - & - & - & - & - & + & + \\
\hline & MBC & - & - & - & - & + & + & + \\
\hline \multirow[t]{2}{*}{ E. coli } & MIC & - & - & - & + & + & + & + \\
\hline & MBC & - & - & + & + & + & + & + \\
\hline \multirow[t]{2}{*}{ K. pneumniae } & MIC & - & - & - & + & + & + & + \\
\hline & MBC & - & - & + & + & + & + & + \\
\hline
\end{tabular}


During our investigations, the determination of minimal inhibitory concentration was evaluated by observing the inhibitory power of our $T$. articulata (Vahl) essential oil sample at different concentrations to the bacteria tested (Table 3).

Indeed, the essential oil of leaves of T. articulata (Vahl) has shown an important inhibitory effect against the microorganisms studied. All microbial strains were inhibited at the concentration of 9.7 $\mu 1 / \mathrm{ml}$ and were bactericidal at the concentration of $16 \mu \mathrm{l} / \mathrm{ml}$. The most sensitive microorganism to leave essential oil was Staphylococcus aureus mestizo whose growth was inhibited at the low concentration of $2.4 \mu \mathrm{l} / \mathrm{ml}$ for the MIC and $4.86 \mu \mathrm{l} / \mathrm{ml}$ for the MBC. Following these results, the essential oil of Tetraclinis articulata (Vahl) from the Khenifra (Morocco) region exhibited very interesting antibacterial characteristics on the microorganisms tested. This is consistent with investigations by Bourkhiset al., who have shown that the species Tetraclinis articulata (Vahl) inhibits the mycelial development of Staphylococcus aureus and has significant antimicrobial activity ${ }^{9}$ (Bourkhiss $\mathrm{M}$ and al., 2007). The antimicrobial properties of the essential oils of several aromatic and medicinal plants have been attributed to their chemical profile and especially to terpene alcohols ${ }^{19-21}$.

The antibacterial activity of the essential oil T. articulata (Vahl) of the Khenifra-(Morocco) region is due to its chemical profile. It should be noted that the essential oils are characterized by the dominance of esters with a percentage of $39.32 \%$ more precisely related to the presence of bornyl acetate with a percentage of $38.34 \%$, the latter is known for its antibacterial power. Indeed, a study showed that the essential oils of Thymus longicaulis, having two chemotypes rich in geranyl acetate for the first and a-terphenyl acetate for the second, possess a high antimicrobial activity ${ }^{20}$. The essential oil of T.articulata (Vahl) from the region of Essaouira (Morocco), which presents as chemotypes bornyl acetate and $\alpha$-pinene, has marked a significant inhibitory activity and Bourkhis and al., have reported that $\alpha$-pinene has no inhibitory power, this confirms that bornyl acetate is the active ingredient, responsible for the antimicrobial activity observed by Bourkhis M et al. ${ }^{9}$.

However, the synergistic effect between all these chemical constituents should also be taken into account for the antimicrobial activity ${ }^{21}$.

According to our results, the $\mathrm{MBC} / \mathrm{MIC}$ ratios are less than 3 for all the strains, so the essential oil of the leaves of $T$. articulata (Vahl) has a bactericidal capacity towards the strains tested.

\section{Conclusion}

The detailed analysis of the essential oils of the leaves, twigs and fruits of T. articulata (Vahl) from
Morocco led to the identification of 33 compounds for the leaves, 28 for the branches and 20 for the fruits.

The results obtained show differentiation in yield and composition of the essential oil of T.articlata Vahl) from one part to another. These results are different from those reported in the literature which shows the influence of biotic and abiotic factors on T.articulata (Vahl), The antibacterial activity of the essential oil of the leaves of T.articulata (Vahl) shows activity via the strains tested.

\section{References}

1- P. Boudy, Économie forestière Nord-Africaine : II, Fasc1 : monographie des essences forestières. Paris, Larousse, 1950.

2- JE. Dakak, La qualité du bois de Thuya de Maghreb (Tetraclinis articulata) et ses conditions de développement sur ses principaux sites phytoécologiques de son bloc méridional au Maroc. Nancy, France, National School of Rural Engineering, Waters and Forests, 2002.

3- D.R.E.F. (Direction Régionale des Eaux et Forêts), Thuya : importance écologique et économique, Florae Libycae Prodromus. Genève, Romet, 2002, 330.

4- K. Hadjadj and A. Letreuch Belarouci, Bibliographic synthesis about the barbary thuja (Tetraclinis articulata (Vahl) Mast.), Geo-EcoTrop, 2017, 41, 1, 13-27.

5- M. Hachi, T. Hachin, N. Belahbib, J. Dahmani, L. Zidane, Contribution à l'étude floristique et ethnobotanique de la flore médicinale utilisée au niveau de la ville de Khénifra (Maroc), International Journal of Innovation and Applied Studies, 2015, 11, 754-770.

6- H. Zerkani, I. Tagnaout, T. Zair, Ethnobotanical survey and inventory of medicinal flora in the rural municipalities of Ait Ishaq, Tighassaline, El-Hammam and Ageulmam azegza-Khenifra province, Morocco, Journal of Chemical and Pharmaceutical Research, 2015, 7(8), 611-627.

7- A. Ziyyat, A. Legssyer, H. Mekhfi, A. Dassouli, M. Serhrouchni, W. Benjelloun, Phytotherapy of hypertension and diabetes in Oriental Morocco. Journal of Ethnopharmacology, 1997, 58, 45-54.

8- J. Bellakhdar, La pharmacopée marocaine traditionnelle. Médecine arabe ancienne et savoirs populaires, Paris - Rabat, Ibis Press Eds Le Fennec,1997, 764.

9- M. Bourkhiss, M. Hnach, B. Bourkhiss, M. Ouhssine, A. Chaouch, Composition chimique et propriétés antimicrobiennes de l'huile essentielle extraite des feuilles de Tetraclinisarticulata (Vahl) du Maroc. Afrique Science, 2007, 03(2), 232-242.

10- J.F. Clevenger, Apparatus for the determination of volatile oil. J. Am. Pharm. Assoc, 1928, 17(4), 346-351. 
11- Afnor, Huile essentielle, recueil des normes françaises. 5th edition, échantillonnage et méthodes d'analyse, 2 spécifications, AFNOR, Paris ,1996.

12- E. Kováts, Gas chromatographic characterization of organic substances in the retention index system. Advances in Chromatography, 1965, 1, 229-247.

13- R.P. Adams, Identification of Essential Oils Components by Gas Chromatography/Mass Spectroscopy,Allured, Carol Stream, IL. 4th edition, 2007, 804.

14- F.J. Pérez, J. Ormeño-Nuñez, Root exudates of wild oats: Allelopathic effect on spring wheat. Phytochemistry 1991, 30:2199-2202.

15- E.H. Lennette, J.P. Truant, C.H. Spaulding, C. Abella, Manual de microbiología clínica, Salvat Editores, 1981.

16- F.B. Toumi, M. Benyahia, L. Hamel, H. Mohamedi, L. Boudaghen, Étude comparative de la composition chimique des huiles essentielles de Tetraclinis articulata (Vahl) Masters originaire d'Algérie. Acta Bot. Gallica, 2010, 158 (1), 93-100.

17- B. Bourkhiss, M. Ouhssine, M. Hnach, M. Bourkhiss, B. Satrani and A.
Farah, Composition chimique et bioactivié de 1'huile essentielle des rameaux de Tetraclinis articulata,Bull. Soc. Pharm. Bordeaux, 2007, 146, 75-84.

18- AF.Barrero, MM.Herrador, P.Arteaga, J.Quilez, M.Akssira, F.Mellouki, S.Akkad ,Chemical composition of the essential oil of leaves and wood of Tetraclinis articulata(Vahl) Masters, J .Ess. Oil. Res, 2005, 17, 166-168.

19- B. Satrani , A. Farah , M. Talbi , Effet de la distillation sur la composition chimique et l'activité antimicrobienne des huiles essentielles de Myrte (Myrtuscommunis L.) du Maroc. Acta Bot. Gallica, 2006, 153(2), 235-242.

20- O. Tzakou, E. Verykokidou, V. Roussis, L. Chinou, Chemical Composition and Antibacterial Properties of Thymus longicaulis subsp. chaoubardii Oils: Three Chemotypes in the Same Population, Journal of Essential Oil Research, 1998, (10), 97-99.

21- S.O.S. Hassane, M. Ghanmi, B. Satrani, et al., Composition chimique et bioactivité des huiles essentielles de deux provenances d'Ocimum canum S. de l'île de la Grande Comore. Phytotherapie,2011,9,18-24. 